\title{
Climate warming drives divergence of montane butterfly communities in Southern Italy
}

\author{
Lucia Santorufo $^{1}$ (1) $\cdot$ Annamaria lenco $^{2} \cdot$ Stefano Scalercio $^{3}$ \\ Received: 25 May 2020 / Accepted: 25 April 2021 / Published online: 21 May 2021 \\ (C) The Author(s) 2021
}

\begin{abstract}
Because of climate change, many insect species are shifting their altitudinal and latitudinal ranges, including Mediterranean butterflies, particularly in mountainous regions. In this study, we evaluated changes in butterfly communities over time, sampled in 1975, 2004, and 2012, in relation to their altitude and two indices representing the climate envelopes of species within a given community: CTI (Community Temperature Index) and CPI (Community Precipitation Index). The study took place in a protected area where we found strong changes in community compositions over the 37 -year study period. There was no vertical stratification of communities in 1975, but became significantly so in 2004 and 2012. Likewise, CTI and CPI were correlated with altitude only in 2004 and 2012. Over time, CTI increased at lower altitudes, indicating an increase in species associated with higher temperatures, and was stable or decreased at higher altitudes. CPI showed opposing trends, decreasing at lower altitude of communities and increasing in higher altitude communities. This resulted in asymmetric changes along the altitudinal gradient. The highest elevations (>1900 m) shifted towards butterfly species that are more associated with colder, wetter habitats, and lower elevations shifted towards species more associated with hotter, drier habitats. In conclusion, changes in butterfly communities were consistent with expectations from observed changes of temperatures and precipitations at low altitudes and mid-altitudes, but not at the highest altitudes. This counter-intuitive result may be due to land-use changes following creation of a national park in 1993 that encompassed the sample sites, but we lack the data to test this hypothesis.
\end{abstract}

Keywords Climate change $\cdot$ Lepidoptera $\cdot$ Italy $\cdot$ Community Temperature Index $\cdot$ Community Precipitation Index

\section{Introduction}

This climatic trend of the past decades and the increase of frequent extreme weather events (EWEs) have significantly modified the distribution of biota around the World (Thomas 2010). Climatic projections for the next future depict an increase of warm and dry conditions, at a much higher rate than those observed in the recent past (Siegmund et al. 2019). The causal effects of EWEs can

Communicated by Wolfgang Cramer

Lucia Santorufo

lucia.santorufo@unina.it

1 Department of Biology, University of Naples Federico II, Via Cinthia, 80126 Napoli, Italy

2 Caulonia Marina, Reggio Calabria, Italy

3 Research Centre for Forestry and Wood, Council for Agricultural Research and Economics, 87036 Rende, Italy be detected more easily than those of global climate change as the former can be explored by planning ad hoc studies also after their occurrence (Altwegg et al. 2017), whilst the latter can only be inferred, thanks to the presence of longterm monitoring programs or, at least, when past standardized data are available. The Mediterranean Basin is regarded as one of the hotspots of global warming on Earth (Giorgi 2006) because it is subject to an increase of temperature and a decrease of precipitation, and to an increasing frequency of EWEs (Diffenbaugh et al. 2007; Gao and Giorgi 2008). Thanks to the presence of several glacial refugia, the Mediterranean Basin also represents an important biodiversity hotspot (Myers et al. 2000) hosting several endemic species (Médail and Quézel 1999; Médail and Diadema 2009; Blondel et al. 2010). Despite the importance of this geographic area for the conservation of biodiversity, longterm monitoring schemes involving the effects of climatic changes on animal species are only available for few Mediterranean countries, even in the case of appealing taxa such as butterflies (van Swaay et al. 2008). 
Lepidoptera monitoring has proven to be a useful tool for evaluating the effects of climate change around the World (Parmesan et al. 1999; Roy and Sparks 2000; Visser and Holleman 2001; Wilson et al. 2005; Schweiger et al. 2008; Bell et al. 2019). A study carried out in Spain demonstrated that over the past decades, butterfly communities shifted upward by approximately $293 \mathrm{~m}$ in mountainous regions, resulting in a net loss of diversity (Wilson et al. 2007). At lower altitudes, a decline of high-elevation species and a general increase in semi-natural habitats of thermophilous ones have been observed, suggesting a causal effect of climate warming on the composition of butterfly communities (Zografou et al. 2014). Short-term changes are less pronounced and cannot be univocally attributed to the recent increases in temperature, as individual species population dynamics can conceal such low level of changes (Zografou et al. 2014; Cerrato et al. 2019). Studies concerning individual species confirm the results obtained for the entire species assemblages, showing an elevational upward shift of about $200 \mathrm{~m}$ of their range (Wilson et al. 2005; Scalercio et al. 2014). Nevertheless, the upward shift of species distribution is not always coupled with a reduction of population size. Interestingly, Erebia cassioides showed an increased population size coupled with a range contraction to the top of the Pollino Massif in southern Italy, suggesting asymmetric effects of climate changes along the altitudinal gradient (Scalercio et al. 2014).

An increasing number of papers are devoted to describing the effects of climate change on the latitudinal and altitudinal range of butterflies. Studies across southern Europe (Wilson et al. 2005, 2007; Zografou et al. 2014; Cerrato et al. 2019), and other geographic areas (Pounds et al. 1999; Shoo et al. 2006; Despland et al. 2012; Molina-Martínez et al. 2013; Dewan et al. 2019), tend to lump high-elevation sites together into one "high" altitudinal band which fails to consider potential differences in species' responses to climate change within montane habitats. Specifically, mountaintop alpine environments often differ considerably from those just at or below treeline, although they are all typically considered "high elevation" habitats.

The Calabria region, the southernmost tip of the Italian Peninsula, is a perfect area to study the consequences of global warming as in southern Italy precipitations decreased by $10 \%$ relative to the mean of the standard period 1961-1990 and the mean minimum temperatures increased by $1.3{ }^{\circ} \mathrm{C}$ (Brunetti et al. 2006). Climate projections for the 21 st century also show a significant warming and a general reduction of precipitation (Bucchignani et al. 2016) for this geographic area. Moreover, it represents one of the most important glacial refugia for continental biota (Konnert and Bergmann 1995; Médail and Diadema 2009; Grill et al. 2009; Andersen et al. 2019), with a strong altitudinal gradient, hosting several populations of Lepidoptera at their southern range limit (Scalercio 2009;
Infusino et al. 2016; Greco et al. 2018). According to available climatic scenarios, in this area, we can expect a very high rate of local extinctions along with the expected loss of habitat suitable for cold-adapted species (Scalercio 2009; Scalercio et al. 2014). However, the key point that allows us to carry out this study is the availability of standardized quantitative butterfly data collected on the Pollino Massif, the highest southern mountain with relict alpine prairies, in the year 1975 by Balletto et al. (1977). The aim of the current study is to describe ongoing altitudinal changes in butterfly communities in a protected area of a Mediterranean massif, at a finer altitudinal resolution than most other studies. As the establishment of protected areas could be expected to improve butterfly habitat conditions, we hypothesize the mitigation of global warming effects on butterfly communities in the Pollino National Park. After the establishment of the national park in 1993, there was a marked decrease in grazing mainly at high altitudes where the core area of the park is located (Scalercio S., personal observation), but there are no official data for this. Unfortunately, we also lack data concerning changes in vegetation cover, but it is known that decreased cow pressure on vegetation can led to a taller grass cover and to an increased forested surface (Carmel and Kadmon 1999; Sternberg et al. 2000).

To achieve the aims of this study, in 2004 and 2012, we resampled most of the sites monitored in 1975, comparing abundance and presence/absence data along the altitudinal gradient. Then, in order to assess the association between main climatic parameters and butterfly communities, we computed the Community Temperature Index (CTI) and the Community Precipitation Index (CPI), functioning as biothermometers that make it easier to summarize and communicate changes in community compositions.

\section{Material and methods}

\section{Study area}

The study area was included entirely within the Pollino National Park, one of the largest National Parks in South Italy with a surface of about 190,000 ha (Fig. 1). It is a mountainous territory with a large area above $1800 \mathrm{~m}$ of altitude and five large peaks over $2000 \mathrm{~m}$ (Serra Dolcedorme, Monte Pollino, Serra del Prete, Serra delle Ciavole, and Serra Crispo). Alpine prairies are present above the tree line. High-altitude natural grasslands are characterized by Festuca bosniaca and Carex kitaibeliana. Pasturelands inside the beech belt are composed of large clearings covered by Festuca violacea-Meum athamanticum grasslands. The treeline $(1800-1900 \mathrm{~m})$ is largely influenced by grazing or other anthropic factors that have led to the development of a wide variety of xeric or mesic herbaceous biotopes in its 


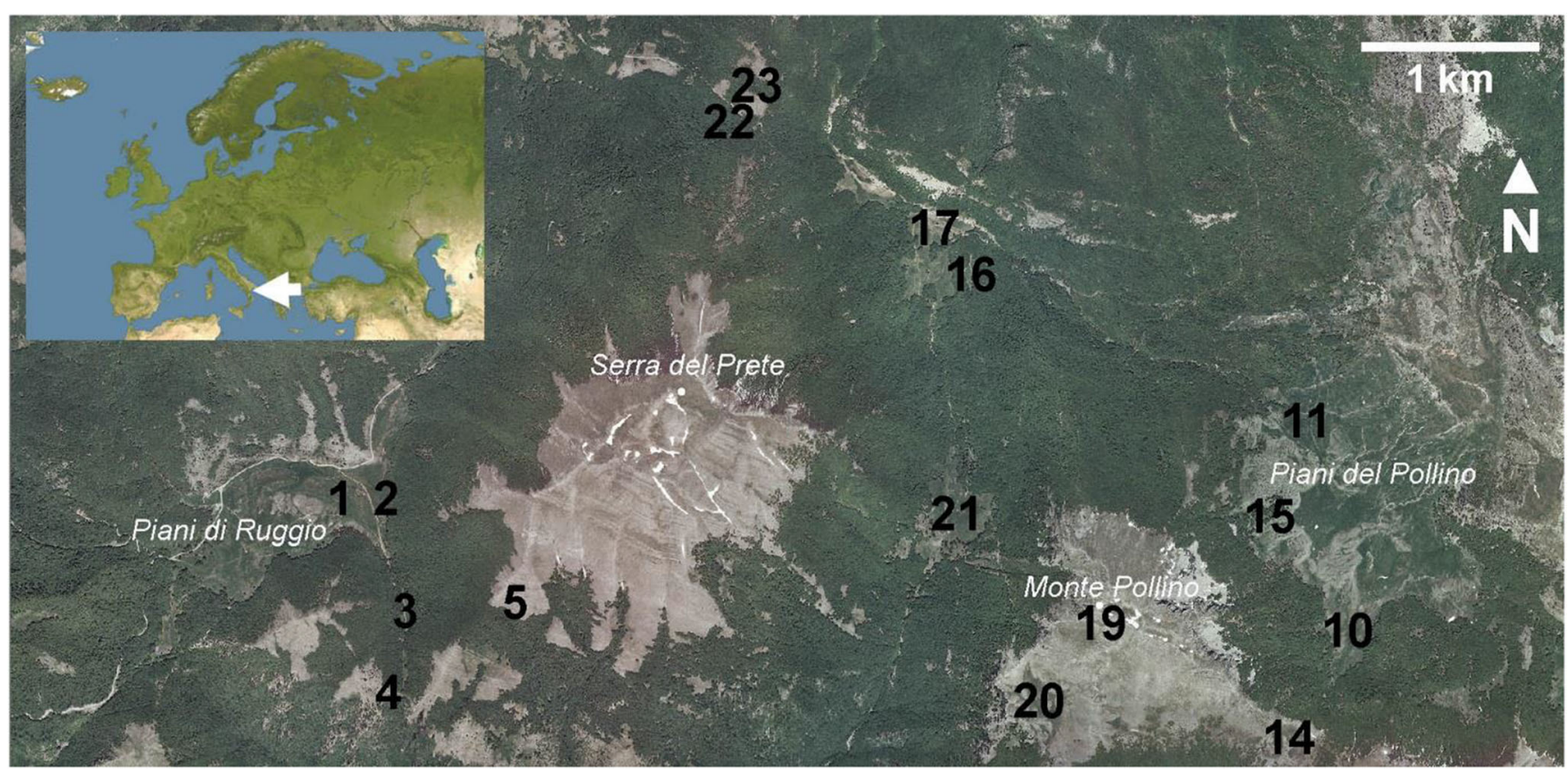

Fig. 1 Study area is indicated by a white arrow. Numeric codes represent monitored sites and indicate their location

surroundings. However, although cow grazing was strongly reduced by the establishment of the National Park, the tree line was quite stable as demonstrated by old pictures showing that sub-vertical rocky slopes slow down the expected upward shift of European beech forest (see Tamanini 1961). Karstic depressions around 2000-2100 m host scattered patches of acidophilic Nardus grass mats (Nardo-Luzuletum pindicae, known in the Corine classification as 36.381: Subalpine southern Italian mat-grass swards) (Brandmayr et al. 2002; Pizzolotto et al. 2010).

The climate of the Pollino National Park varies according to the altitude from summer-arid true Mediterranean to mountain Mediterranean. The heaviest rains are concentrated from November to February. Climate data for the area are fragmentary and available for sites at lower altitude than that of the study area, but only few kilometers apart. Temperatures are available for the Castrovillari meteorological station (400 m a.s.1.), while rainfall data are available for Castrovillari and Campo Tenese (1400 m a.s.l.) meteorological stations. Temperature and precipitation trends of the past decades were analyzed by Scalercio et al. (2014), and they seem to be consistent with those found by Brunetti et al. (2006) in Southern Italy as a whole. At low altitudes, temperatures show an evident increase of maxima with a value of $-1.5^{\circ} \mathrm{C}$ below the mean of the $1925-2012$ period in 1985 and a value of $+1.0^{\circ} \mathrm{C}$ in 2012. The same occurred for the minima with a value of $-1.5^{\circ} \mathrm{C}$ in 1986 and of $+2.1^{\circ} \mathrm{C}$ in 2012 . The rainfall dropped rapidly starting from the 1970 s, with about $1700 \mathrm{~mm}$ (10-year running mean) of precipitation registered in the year 1970 at the Campo Tenese meteorological station, dropping to about 950mm in 2012.

\section{Butterfly monitoring}

Communities were sampled for the first time by Balletto et al. (1977) during the year 1975 within 23 sites. We repeated the sampling in most of these sites in 2004 and 2012, after 29 and 37 years respectively. As a result of excluding sites below $1400 \mathrm{~m}$ and three sites whose exact locations we could not find, we sampled a total of 16 sites ranging from 1470 to $2220 \mathrm{~m}$ in altitude (Table 1). Butterfly monitoring was carried out from early-July to late-August as in Balletto et al. (1977), corresponding to the period of maximum abundance and richness of butterflies in Mediterranean mountainous areas. During this period, four sampling sessions were carried out, separated by no less than 14 , and no more than 20 days during optimal weather conditions for butterfly activity (sunny days, no or low wind speed). In previous studies on the effects of climate change on Mediterranean butterfly communities along altitudinal gradients, not enough details were provided on changes occurring in the highest altitude communities as sites were grouped in wide altitudinal band (Wilson et al. 2005, 2007; Cerrato et al. 2019). In this study, we focused our attention only on the highest sites sampled by Balletto and collaborators, grouping sites into altitudinal band: (i) low altitudinal band (1470-1575m a.s.1.) includes 7 sites mainly composed of beech forest margins and pastures, (ii) medium altitudinal band (1610-1825m a.s.1.) includes 5 sites mainly composed of beech forest margins and pastures, and (iii) high altitudinal band (1900-2220m a.s.1.) includes 4 sites all dominated by Seslerio-Brometum grasslands located above the tree-line.

We utilized a different sampling method than that used by Balletto et al. (1977). In fact, whilst Balletto et al. (1977) 
Table 1 Location of sampling sites and description of the dominant habitat. Site number codes correspond to those of Balletto et al. (1977). From Scalercio et al. (2014), modified

\begin{tabular}{|c|c|c|c|c|c|}
\hline Site & Locality & Dominant habitat & $\begin{array}{l}\text { Latitude- } \\
\text { longitude }\end{array}$ & $\begin{array}{l}\text { Altitude } \\
\text { (m a.s.1.) }\end{array}$ & $\begin{array}{l}\text { Altitudinal } \\
\text { band }\end{array}$ \\
\hline 19 & Monte Pollino & $\begin{array}{l}\text { Seslerio-Brometum/Festuca } \\
\text { bosniaca grasslands }\end{array}$ & $\begin{array}{l}39.9067^{\circ} \mathrm{N} \\
16.1826^{\circ} \mathrm{E}\end{array}$ & 2200 & High \\
\hline 14 & Serra Dolcedorme & Seslerio-Brometum & $\begin{array}{l}39.9002^{\circ} \mathrm{N} \\
16.2001^{\circ} \mathrm{E}\end{array}$ & 1975 & High \\
\hline 20 & Monte Pollino & Seslerio-Brometum & $\begin{array}{l}39.9015^{\circ} \mathrm{N} \\
16.1875^{\circ} \mathrm{E}\end{array}$ & 1920 & High \\
\hline 5 & Serra del Prete & Seslerio-Brometum & $\begin{array}{l}39.9075^{\circ} \mathrm{N} \\
16.1410^{\circ} \mathrm{E}\end{array}$ & 1900 & High \\
\hline 15 & Piani del Pollino & Beech forest margin & $\begin{array}{l}39.9117^{\circ} \mathrm{N} \\
16.1995^{\circ} \mathrm{E}\end{array}$ & 1825 & Medium \\
\hline 11 & Piani del Pollino & Nardetum & $\begin{array}{l}39.9160^{\circ} \mathrm{N} \\
16.2054^{\circ} \mathrm{E}\end{array}$ & 1810 & Medium \\
\hline 10 & Piani del Pollino & Festucetum violaceae & $\begin{array}{l}39.9049^{\circ} \mathrm{N} \\
16.2042^{\circ} \mathrm{E}\end{array}$ & 1800 & Medium \\
\hline 21 & Colle Gaudolino & Nardetum & $\begin{array}{l}39.9123^{\circ} \mathrm{N} \\
16.1773^{\circ} \mathrm{E}\end{array}$ & 1680 & Medium \\
\hline 4 & $\begin{array}{l}\text { Belvedere di } \\
\text { Malvento }\end{array}$ & Beech forest clearing & $\begin{array}{l}39.9026^{\circ} \mathrm{N} \\
16.1370^{\circ} \mathrm{E}\end{array}$ & 1610 & Medium \\
\hline 3 & Vallone di Malvento & Beech forest clearing & $\begin{array}{l}39.9066^{\circ} \mathrm{N} \\
16.1381^{\circ} \mathrm{E}\end{array}$ & 1575 & Low \\
\hline 23 & Colle dell'Impiso & Xerobrometum & $\begin{array}{l}39.9341^{\circ} \mathrm{N} \\
16.1630^{\circ} \mathrm{E}\end{array}$ & 1575 & Low \\
\hline 22 & Colle dell'Impiso & Beech forest margin & $\begin{array}{l}39.9342^{\circ} \mathrm{N} \\
16.1620^{\circ} \mathrm{E}\end{array}$ & 1570 & Low \\
\hline 2 & Piano di Ruggio & Beech forest margin & $\begin{array}{l}39.9127^{\circ} \mathrm{N} \\
16.1368^{\circ} \mathrm{E}\end{array}$ & 1530 & Low \\
\hline 1 & Piano di Ruggio & Festucetum violaceae & $\begin{array}{l}39.9130^{\circ} \mathrm{N} \\
16.1342^{\circ} \mathrm{E}\end{array}$ & 1510 & Low \\
\hline 16 & Piano di Vacquarro & Beech forest clearing & $\begin{array}{l}39.9254^{\circ} \mathrm{N} \\
16.1778^{\circ} \mathrm{E}\end{array}$ & 1500 & Low \\
\hline 17 & Piano di Vacquarro & Nardetum & $\begin{array}{l}39.9281^{\circ} \mathrm{N} \\
16.1757^{\circ} \mathrm{E}\end{array}$ & 1470 & Low \\
\hline
\end{tabular}

quantified species abundances as the number of observed individuals per hectare producing density values, we applied a time-constrained method by sampling for $20 \mathrm{~min}$ along a fixed transect within homogeneous habitats according to the Pollard walk protocol (Pollard 1977), producing the number of individuals as abundance data. As our data were not comparable per se with those collected in 1975 , we used relative abundances of species to homogenize the data.

Species are named according to Wiemers et al. (2018).

\section{Data analysis}

The unavailability of a species/individual's matrix for 1975 allowed us to use only presence/absence non-parametric estimators of species richness to compute sampling completeness. We selected the Chao2 richness estimator (Chao2 Mean) and its standard deviation computed after 100 randomizations of samples running EstimateS 9.1.0 (Colwell 2013). Sampling completeness was computed in terms of proportion of species diversity sampled versus the species diversity estimated. Sampling efficiency was higher than the $94 \%$ in the year 1975, being between 84 and $98 \%$ in 2004 and between 71 and $94 \%$ in 2012.

In order to explore the dissimilarities among butterfly communities, different non-metric multidimensional scaling (NMDS) using the Bray-Curtis index was performed. In particular, we analyzed butterfly species composition (quantitative and presence-absence) among the different altitudinal bands in each year. Differences in butterfly communities over the years and altitudinal bands were tested by permutational multivariate analysis of variance using distance matrices (ADONIS function).

To assess which species significantly affected similarity along the altitudinal gradient, we searched for the changes across the years of altitudinal band indicator species. Indicator species are defined as the most characteristic species 
of a given group that can be used as indicators of communities (De Caceres et al. 2010). This is an extension of the original Individual Indicator Value method (IndVal) proposed by Dufrêne and Legendre (1997), which can be used to measure the degree of association between the target species for both individual site groups and each of the possible combinations of site groups. To run statistical analyses, we used the software R 3.6.1 (R Core Team 2019), using the "vegan" package (Oksanen et al. 2014) for NMDS and Permanova analyses and using the "multipatt" function of the package "indicspecies" (De Cáceres and Jansen 2016), with "IndVal.g" as association index on presence/absence data to identify indicator species for each altitudinal band in a multilevel pattern analysis.

We computed the Community Temperature Index (CTI) and the Community Precipitation index (CPI) increasingly in use to measure the responses to climate change of animal communities. They were computed starting from the climatic niche of individual species, determined by abiotic parameters registered in their occurrence sites. In this paper, we used data mined from CLIMBER (Schweiger et al. 2014), where several climatic variables for European butterfly species were reported, at a resolution of $50 \mathrm{~km}$. The scale at which climatic requirements are estimated can affect the possibility of finding a link between population trends and climate change, especially on a regional scale such as in this study, where in the same grid cell of $50 \mathrm{~km}$, we can find alpine prairies and coastal vegetation. Among available climatic variables, we selected the maximum temperature (T.max, mean of monthly maximum temperature) and the minimum precipitation (Prec.min, mean of monthly minimum precipitation) measured across the entire European range of butterflies. The maximum temperature is largely known to determine a rapid range expansion of thermophilous species (Sparks et al. 2005; Battisti et al. 2006), whereas the minimum precipitation can contribute to the decrease of butterfly diversity in a water deficient area such as the Mediterranean Basin (Stefanescu et al. 2011). CTI and CPI are the means of these variables computed according to the relative abundance of any species composing a given community and their formulas can be written as:

$\mathrm{CTI}=\sum_{s=1}^{n} \mathrm{~T} \cdot \max \times$ Relative.abundance

$\mathrm{CPI}=\sum_{s=1}^{n}$ Prec.min $\times$ Relative. abundance

where $n$ is the number of species in the community and the relative abundance is the species' abundance divided by the abundance of all species.

We carried out Pearson correlations between these community climatic indices and altitude for each sampling year, also searching for significant differences of the slopes of the regression lines among years using a $t$-test with the standard error of the regression models as the error term (R Core Team 2019).

Recently some authors have stated that these indices should be used with caution as they can respond not only to changes in the climate spaces of species but also to some covariates linked to significant changes in land use (Barnagaud et al. 2012). A model-based approach has been proposed for improving community weighted indices (Bowler and BöhningGaese 2017). In our case, the bias due to land use change can be considered weaker than those observed in cases of land use changes like those due to the conversion of forest to agricultural lands. This study was conducted in a natural protected territory where we only observed the reduction of cow grazing pressure on vegetation during the study period.

\section{Results}

During the 3 years of surveys, we observed a total of 72 species (Table 2). According to the Chao 2 richness estimator, the overall richness estimated during 2004 and 2012 was 69.9 \pm 5.4 (95\% confidence intervals) and $62.2 \pm 8.7$, respectively, higher than that estimated during 1975 (47.4 \pm 1.8$)$.

A total of 46 species was observed in 1975 , with a richness in individual sites comprised between 4 (site 21) and 25 (site 3 ), and a median value of 13.5 species. During 2004, we registered 63 species and 3491 individuals. The lowest richness values increased to 15 species in sites 11,15 , and 19 , whilst the highest richness values remained stable (26 species in sites 3,4, and 5). This resulted in an increase of median richness to 21.5 species. During 2012, the sample was composed of 50 species and 1172 individuals, with the number of species comprised between 9 (site 20) and 26 (site 4), and a median value of 13 species (Fig. 2). The richness registered during 2004 was significantly higher than that registered during 1975 (Kolmogorov-Smirnov test, $p=0.0019)$ and $2012(p$ $=0.0019)$, whilst no differences were detected between 1975 and $2012(p=0.6325)$.

Seventeen species were registered for only one year, 4 in 1975, 11 in 2004, and 2 in 2012 (Table 2). The list of species grew during the last research years, i.e., those registered only in both 2004 and 2012, and was longer than those lost since 1975 (Table 2). In fact, 13 new entries appeared to be stable in recent communities and, with the sole exception of Polyommatus bellargus, all of them are more common at lower altitudes than those of the study area.

The composition of butterfly communities was in general quite stable among years, always showing Erebia cassioides and Argynnis niobe among the five most abundant species, whilst Lysandra coridon, Satyrus ferula, and Hipparchia hermione appeared twice among them (Table 2). On the other 
Table 2 Relative abundance, as percentage, and occupancy, as number of sites where species were recorded, during study years. Trends in relative abundance were recognized as negative or positive $(-,+)$ when the same sign was registered across all years; they were considered strong $(--,++)$ when their magnitude is higher than the $100 \%$ at least between 2 study years, and higher than the $1 \%$ in absolute terms between the lowest and the highest value. Trends in occupancy were recognized as negative or positive $(-,+)$ when the same sign was registered across all years. A positive trend was also recognized when a species was absent in the first year and constantly recognized during last two study years. Their changes were considered strong $(--,++)$ when at least the half of sites were lost or gained compared to the first sampled year and when a given species was present in at least three sites during one of the study years

\begin{tabular}{|c|c|c|c|c|c|c|c|c|}
\hline \multirow[b]{2}{*}{ Species } & \multicolumn{4}{|c|}{ Relative abundance $(\%)$} & \multicolumn{4}{|c|}{ Occupancy } \\
\hline & 1975 & 2004 & 2012 & Trend & 1975 & 2004 & 2012 & Trend \\
\hline Chazara briseis & 4.88 & 0 & 0 & - & 1 & 0 & 0 & - \\
\hline Coenonympha dorus & 0.09 & 0 & 0 & - & 1 & 0 & 0 & - \\
\hline Leptotes pirithous & 0.12 & 0 & 0 & - & 1 & 0 & 0 & - \\
\hline Nymphalis polychloros & 2.46 & 0 & 0 & - & 4 & 0 & 0 & - \\
\hline Lycaena tityrus & 1.30 & 0.03 & 0 & - & 5 & 1 & 0 & -- \\
\hline Lycaena virgaureae & 2.90 & 0.43 & 0 & - & 4 & 3 & 0 & - \\
\hline Thymelicus sylvestris & 0.60 & 0.06 & 0 & - & 2 & 1 & 0 & - \\
\hline Pyrgus carthami & 0.70 & 0.09 & 0 & - & 4 & 2 & 0 & - \\
\hline Brintesia circe & 0.63 & 0.26 & 0 & - & 1 & 7 & 0 & $=$ \\
\hline Maniola jurtina & 0.30 & 0.14 & 0 & - & 2 & 3 & 0 & $=$ \\
\hline Thymelicus lineola & 0.16 & 0.09 & 0 & - & 3 & 3 & 0 & $=$ \\
\hline Erebia cassioides & 9.95 & 10.03 & 18.26 & $=$ & 10 & 6 & 5 & -- \\
\hline Hipparchia semele & 8.92 & 2.95 & 1.11 & - & 13 & 12 & 6 & - \\
\hline Melanargia russiae & 2.60 & 1.32 & 0.17 & - & 7 & 5 & 1 & -- \\
\hline Melitaea didyma & 2.42 & 0.06 & 0.09 & $=$ & 5 & 2 & 1 & - \\
\hline Aglais urticae & 0.42 & 0.17 & 0.17 & $=$ & 4 & 2 & 2 & - \\
\hline Polyommatus ripartii & 4.09 & 1.89 & 2.82 & $=$ & 5 & 4 & 3 & - \\
\hline Fabriciana niobe & 10.30 & 4.55 & 16.55 & $=$ & 14 & 16 & 16 & $=$ \\
\hline Argynnis pandora & 0.42 & 1.15 & 0.51 & $=$ & 3 & 10 & 3 & $=$ \\
\hline Hesperia comma & 6.09 & 0.83 & 2.65 & $=$ & 7 & 12 & 10 & $=$ \\
\hline Hipparchia hermione & 7.27 & 2.75 & 4.18 & $=$ & 11 & 14 & 13 & $=$ \\
\hline Argynnis paphia & 0.23 & 0.26 & 0.09 & - & 1 & 3 & 1 & $=$ \\
\hline Lasiommata megera & 0.19 & 0.52 & 0.60 & + & 2 & 9 & 5 & $=$ \\
\hline Melanargia galathea & 7.00 & 0.32 & 1.28 & $=$ & 10 & 3 & 4 & $=$ \\
\hline Speyeria aglaja & 1.12 & 0.37 & 1.28 & $=$ & 5 & 9 & 6 & $=$ \\
\hline Ochlodes sylvanus & 0.63 & 0.14 & 0.17 & - & 3 & 3 & 2 & $=$ \\
\hline Pieris brassicae & 0.14 & 1.52 & 0.85 & $=$ & 2 & 15 & 5 & $=$ \\
\hline Pieris rapae & 0.98 & 0.69 & 0.60 & - & 5 & 10 & 4 & $=$ \\
\hline Plebejus argus & 1.07 & 0.80 & 0.85 & $=$ & 7 & 7 & 6 & $=$ \\
\hline Lysandra coridon & 3.97 & 48.98 & 8.62 & $=$ & 7 & 16 & 16 & $=$ \\
\hline Polyommatus dorylas & 1.93 & 0.34 & 1.02 & $=$ & 7 & 4 & 2 & $=$ \\
\hline Pyrgus alveus & 0.19 & 0.06 & 0.17 & $=$ & 3 & 2 & 2 & $=$ \\
\hline Satyrus ferula & 3.56 & 5.18 & 5.29 & + & 5 & 8 & 8 & $=$ \\
\hline Vanessa atalanta & 0.30 & 0.09 & 0.09 & $=$ & 2 & 3 & 1 & $=$ \\
\hline Vanessa cardui & 0.07 & 0.69 & 0.34 & $=$ & 2 & 10 & 4 & $=$ \\
\hline Hyponephele lycaon & 2.46 & 1.86 & 1.88 & - & 7 & 8 & 9 & + \\
\hline Celastrina argiolus & 1.16 & 0.17 & 1.28 & $=$ & 1 & 4 & 5 & ++ \\
\hline Coenonympha pamphilus & 0.79 & 0.34 & 2.73 & $=$ & 4 & 6 & 12 & ++ \\
\hline Colias alfacariensis & 1.60 & 0.86 & 4.18 & $=$ & 8 & 11 & 14 & ++ \\
\hline Colias crocea & 0.81 & 2.15 & 2.73 & ++ & 8 & 14 & 12 & ++ \\
\hline Issoria lathonia & 0.35 & 0.63 & 7.34 & ++ & 2 & 8 & 12 & ++ \\
\hline Lycaena hippothoe & 1.28 & 1.98 & 2.2 .39 & ++ & 2 & 3 & 5 & ++ \\
\hline
\end{tabular}


Table 2 (continued)

\begin{tabular}{|c|c|c|c|c|c|c|c|c|}
\hline \multirow[b]{2}{*}{ Species } & \multicolumn{4}{|c|}{ Relative abundance (\%) } & \multicolumn{4}{|c|}{ Occupancy } \\
\hline & 1975 & 2004 & 2012 & Trend & 1975 & 2004 & 2012 & Trend \\
\hline Polyommatus icarus & 1.12 & 1.06 & 4.61 & $=$ & 5 & 10 & 11 & ++ \\
\hline Iphiclides podalirius & 0.70 & 0 & 0.17 & $=$ & 3 & 0 & 2 & $=$ \\
\hline Limenitis reducta & 0.81 & 0 & 0.17 & $=$ & 2 & 0 & 2 & $=$ \\
\hline Polyommatus daphnis & 0.93 & 0 & 0.09 & $=$ & 4 & 0 & 1 & $=$ \\
\hline Aporia crataegi & 0 & 0.19 & 0 & $=$ & 0 & 3 & 0 & $=$ \\
\hline Boloria euphrosyne & 0 & 0.06 & 0 & $=$ & 0 & 2 & 0 & $=$ \\
\hline Brenthis daphne & 0 & 0.03 & 0 & $=$ & 0 & 1 & 0 & $=$ \\
\hline Cupido minimus & 0 & 0.03 & 0 & $=$ & 0 & 1 & 0 & $=$ \\
\hline Cyaniris semiargus & 0 & 0.17 & 0 & $=$ & 0 & 3 & 0 & $=$ \\
\hline Gonepteryx cleopatra & 0 & 0.03 & 0 & $=$ & 0 & 1 & 0 & $=$ \\
\hline Melitaea celadussa & 0 & 0.46 & 0 & $=$ & 0 & 6 & 0 & $=$ \\
\hline Melitaea cinxia & 0 & 0.06 & 0 & $=$ & 0 & 2 & 0 & $=$ \\
\hline Nymphalis antiopa & 0 & 0.03 & 0 & $=$ & 0 & 1 & 0 & $=$ \\
\hline Pararge aegeria & 0 & 0.09 & 0 & $=$ & 0 & 3 & 0 & $=$ \\
\hline Satyrium spini & 0 & 0.06 & 0 & $=$ & 0 & 1 & 0 & $=$ \\
\hline Aricia agestis & 0 & 0.66 & 1.02 & ++ & 0 & 6 & 4 & ++ \\
\hline Erynnis tages & 0 & 0.43 & 0.26 & $=$ & 0 & 4 & 1 & ++ \\
\hline Gonepteryx rhamni & 0 & 0.40 & 0.26 & $=$ & 0 & 5 & 3 & ++ \\
\hline Lampides boeticus & 0 & 0.03 & 0.09 & + & 0 & 1 & 1 & + \\
\hline Lasiommata maera & 0 & 0.03 & 0.34 & + & 0 & 1 & 3 & ++ \\
\hline Lycaena phlaeas & 0 & 0.14 & 0.09 & $=$ & 0 & 4 & 1 & ++ \\
\hline Papilio machaon & 0 & 0.03 & 0.26 & + & 0 & 1 & 3 & ++ \\
\hline Pieris ergane & 0 & 0.09 & 0.17 & + & 0 & 2 & 1 & + \\
\hline Pieris napi & 0 & 0.29 & 1.19 & ++ & 0 & 6 & 4 & ++ \\
\hline Polygonia c-album & 0 & 0.03 & 0.09 & + & 0 & 1 & 1 & + \\
\hline Polyommatus bellargus & 0 & 0.92 & 0.43 & $=$ & 0 & 10 & 4 & ++ \\
\hline Pseudophilotes baton & 0 & 0.06 & 0.09 & + & 0 & 2 & 1 & + \\
\hline Satyrium ilicis & 0 & 0.03 & 0.09 & + & 0 & 1 & 1 & + \\
\hline Spialia sertorius & 0 & 0 & 0.17 & + & 0 & 0 & 1 & $=$ \\
\hline Carcharodus alceae & 0 & 0 & 0.17 & + & 0 & 0 & 1 & $=$ \\
\hline
\end{tabular}

Fig. 2 Box plots of the number of species per site recorded during the three study years. The minimum, the maximum, the sample median, and the first and third quartiles are reported

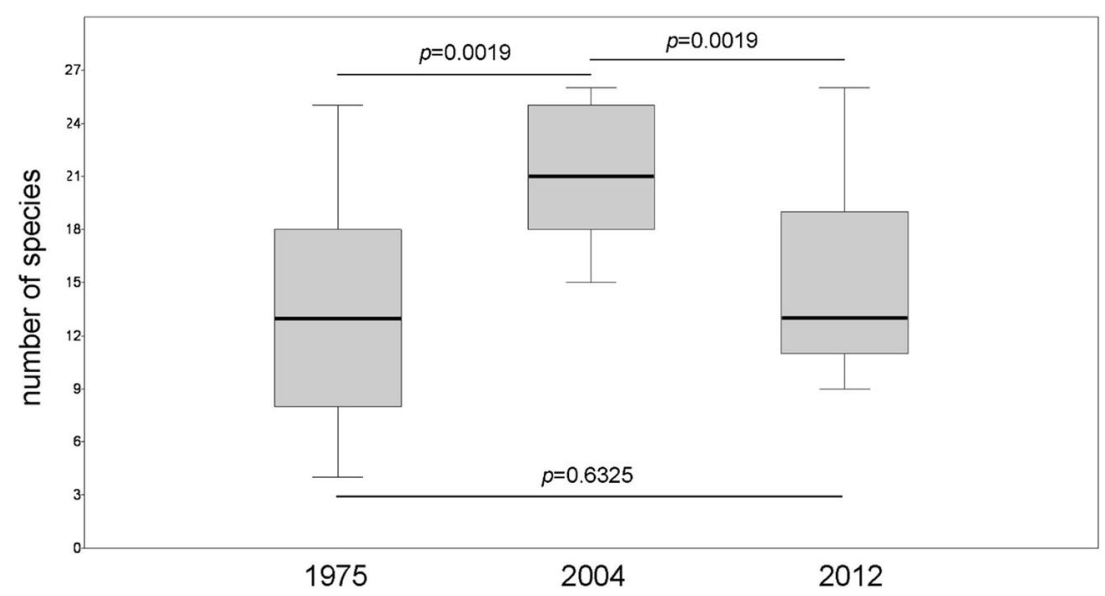


hand, individual species showed strong changes in some cases. The strongest decrease occurred for Chazara briseis that fell from $4.9 \%$ in 1975 to zero, apparently disappearing during the last years. Another remarkable case concerned Lycaena virgaureae representing $2.9 \%$ of the total abundance in 1975 , decreasing to $0.4 \%$ in 2004 , and disappearing in 2012. Significant increases were observed for several common species usually registered during all sampling years, such as Colias crocea and Coenonympha pamphilus. Pieris napi and Aricia agestis were the only species not registered during 1975 , which represented more than $1 \%$ of the total abundance in 2012. During 2004, we observed an outbreak of Lysandra coridon that represented $48.9 \%$ of the total abundance, decreasing in 2012 to abundances comparable to those of 1975.

As observed for relative abundance values, occupancy of species also changed over the years, sometimes corresponding to changes in abundance. In fact, 4 out of 7 species with a strong decrease in occupancy also had a strongly decreased abundance, and only in Erebia cassioides, Hipparchia semele, and Melitaea didyma, the occupancy decreased more than the relative abundance (Table 2). On the other hand, all the 5 species which showed a considerable increase in relative abundance also showed a strong increase in occupancy (Colias crocea, Issoria lathonia, Lycaena hippothoe, Aricia agestis, and Pieris napi), whilst a further 10 species greatly increased only their occupancy (Table 2).

Changes in abundance and distribution of individual species led to changes of indicator species for altitudinal bands. In 1975, the low altitudinal band was the only one with indicator species and they were two mesophilous ones (Table 3). In recent years, marked changes occurred as indicator species of the low altitudinal band were clearly much more thermophilous (Table 3), while new indicator species appeared for the high altitudinal band which previously had been absent.

The communities observed in the different altitudinal bands showed major changes in recent years at community level using both quantitative and presence/absence similarity matrices (Fig. 3). In 1975, no significant differences among communities of the different altitudinal bands were observed, whilst in 2004 and 2012, we observed highly significant differences among them, mainly due to the clear differentiation of the high altitudinal band from the others. In particular, according to quantitative and presence/absence analysis of 2004 (ADONIS, quantitative: $p<0.001$; presence/absence: $p<0.01$ ) and 2012 (ADONIS, quantitative: $p<0.001$; presence/absence: $p<0.01$ ), species composition of low and medium altitude seemed to be more similar to each other than to high altitude, as they were closer in the Cartesian plane (Fig. 3).

Analyzing data by altitudinal bands, we found that both CTI and CPI were quite stable at low altitude, whilst significant changes of opposite signs occurred in the remaining altitudinal bands. Communities became hotter and dryer at medium altitude, colder and wetter at high altitude (Table 4). Consistent with these results, we found no correlations of CTI (Pearson's $\left.r_{1975}=-0.001 ; p=0.998\right)$ and CPI $\left(r_{1975}=\right.$ $0.132 ; p=0.625$ ) with the altitude during 1975, whilst in 2004 and 2012, we found an increasing negative correlation for CTI $\left(r_{2004}=-0.658 ; p=0.006 ; r_{2012}=-0.719 ; p=0.002\right)$ and an increasing positive correlation for CPI $\left(r_{2004}=0.693 ; p=\right.$ $0.003 ; r_{2012}=0.706 ; p=0.002$ ) (Fig. 4). Slope correlations were not significant between 1975 and 2004 (CPI, $p=0.900$; CTI, $p=0.942$ ) and between 1975 and 2012 (CPI, $p=0.970$; CTI, $p-=0.986$ ), whilst it became significant between recent years (CPI, $p \leq 0.0001$; CTI, $p \leq 0.0001$ ), confirming the trend of correlations across years.

\section{Discussion}

In this paper, we found that over the past 37 years, butterfly communities of the Pollino Massif, sampled above $1400 \mathrm{~m}$ of
Table 3 Indicator species calculated with a multi-level pattern analysis based on presence/ absence data for each altitudinal band. Only the significant species for each band and for combination of bands are reported

\begin{tabular}{llllll}
\hline Year & Altitudinalband & Species & IndVal statistics & $\begin{array}{l}p \text { - } \\
\text { value }\end{array}$ & Temp.max \\
\hline 1975 & Low & Hyponephele lycaon & 0.857 & 0.007 & 17.09 \\
1975 & Low & Pyrgus carthami & 0.756 & 0.031 & 15.06 \\
2004 & Low & Aricia agestis & 0.772 & 0.044 & 18.64 \\
2004 & Low & Celastrina argiolus & 0.756 & 0.017 & 18.64 \\
2004 & High & Lycaena hippothoe & 0.866 & 0.010 & 14.72 \\
2004 & High & Erebia cassioides & 0.816 & 0.026 & 14.72 \\
2012 & Low & Hipparchia semele & 0.926 & 0.001 & 16.97 \\
2012 & Low & Melanargia galathea & 0.756 & 0.047 & 17.56 \\
2012 & Low & Pieris napi & 0.756 & 0.049 & 17.56 \\
2012 & Low + Medium & Polyommatus icarus & 0.957 & 0.001 & 18.64 \\
2012 & High & Erebia cassioides & 0.913 & 0.002 & 14.72 \\
\hline
\end{tabular}



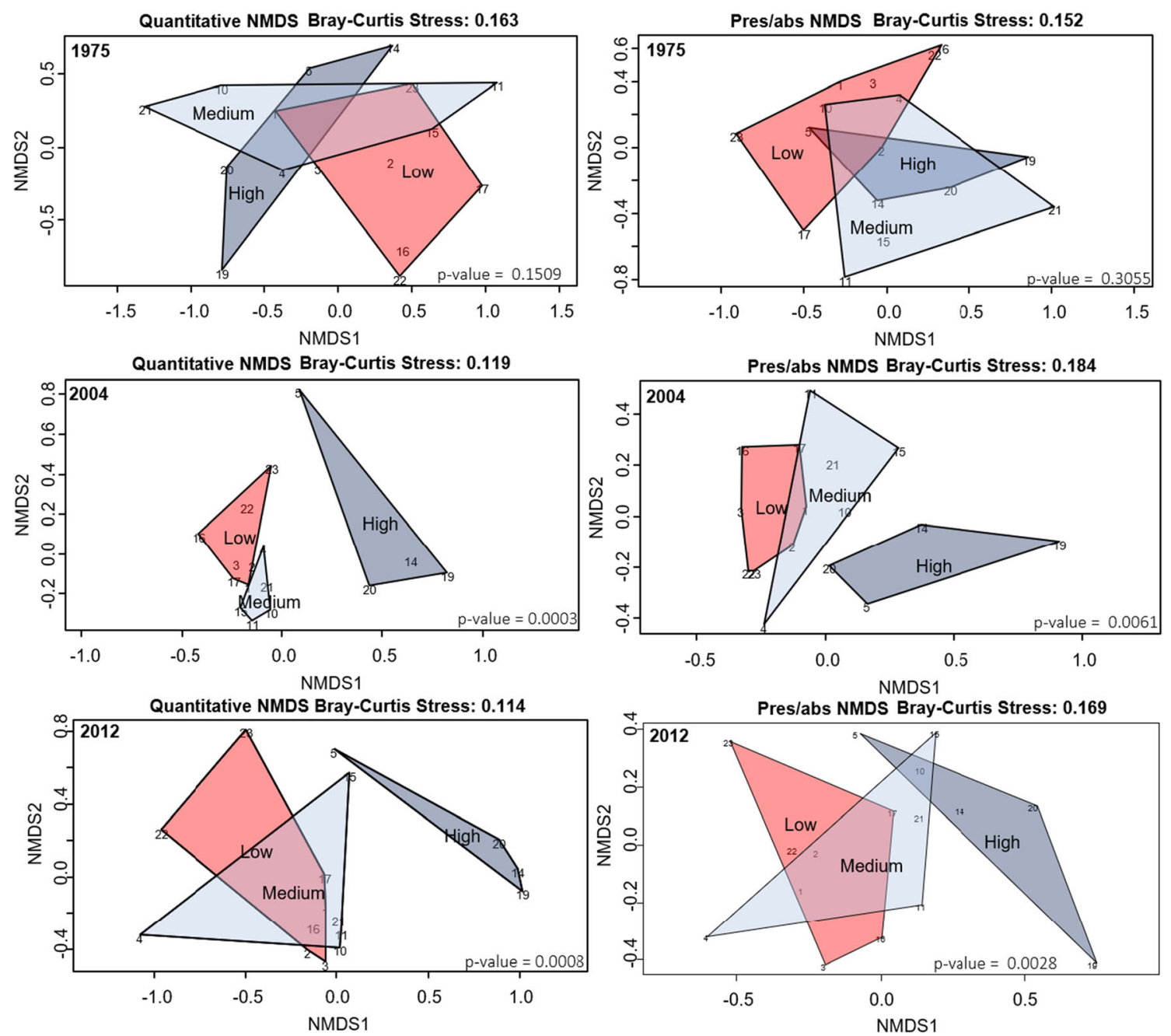

Fig. 3 Graphic displaying the first two axes of the non-metric multidimensional scaling (NMDS) on butterfly species composition found at different mountain altitudes (low, medium, high) in each year of sampling

altitude, showed substantial changes in species abundance and composition. This has led to a vertical stratification of communities only observed in recent years. This pattern stemmed from opposite trends in community composition over time below and above the tree line (near $1900 \mathrm{~m}$ a.s.1.). This was seen as an increasing correlation between Community
(1975, 2004, 2012). Statistical differences in species compositions among the mountain altitude were reported as $p$-value in the graph (permutational multivariate analysis of variance - ADONIS)

Temperature Index and Precipitation Community Index with altitude. Despite having only 3 years of censuses, the changes noted since 1975 appear to be qualitatively similar in the two latter censuses (in both 2004 and 2012), indicating that the changes were not driven by a single nor temporary event, but represent true long-term changes in community
Table 4 Mean values and their standard deviations of Community Temperature Index (CTI) and Community Precipitation Index (CPI) registered for sampled communities $(n$ $=$ number of sites per altitudinal band) during investigated years

\begin{tabular}{|c|c|c|c|c|c|}
\hline & \multirow[t]{2}{*}{ Year } & \multirow[t]{2}{*}{ Overall $(n=16)$} & \multicolumn{3}{|c|}{ Altitudinal band } \\
\hline & & & $\operatorname{Low}(n=7)$ & $\operatorname{Medium}(n=5)$ & $\operatorname{High}(n=4)$ \\
\hline \multirow[t]{3}{*}{ CTI $\left({ }^{\circ} \mathrm{C}\right)$} & 1975 & $16.7 \pm 0.7$ & $16.9 \pm 0.4$ & $16.4 \pm 1.0$ & $16.6 \pm 0.6$ \\
\hline & 2004 & $16.7 \pm 0.5$ & $16.9 \pm 0.2$ & $16.9 \pm 0.2$ & $16.0 \pm 0.2$ \\
\hline & 2012 & $16.9 \pm 0.7$ & $17.2 \pm 0.2$ & $17.3 \pm 0.2$ & $15.9 \pm 0.6$ \\
\hline \multirow[t]{3}{*}{ CPI (mm) } & 1975 & $396 \pm 56$ & $370 \pm 37$ & $422 \pm 76$ & $409 \pm 49$ \\
\hline & 2004 & $353 \pm 46$ & $335 \pm 16$ & $321 \pm 22$ & $423 \pm 28$ \\
\hline & 2012 & $381 \pm 58$ & $355 \pm 22$ & $347 \pm 19$ & $466 \pm 45$ \\
\hline
\end{tabular}


1975
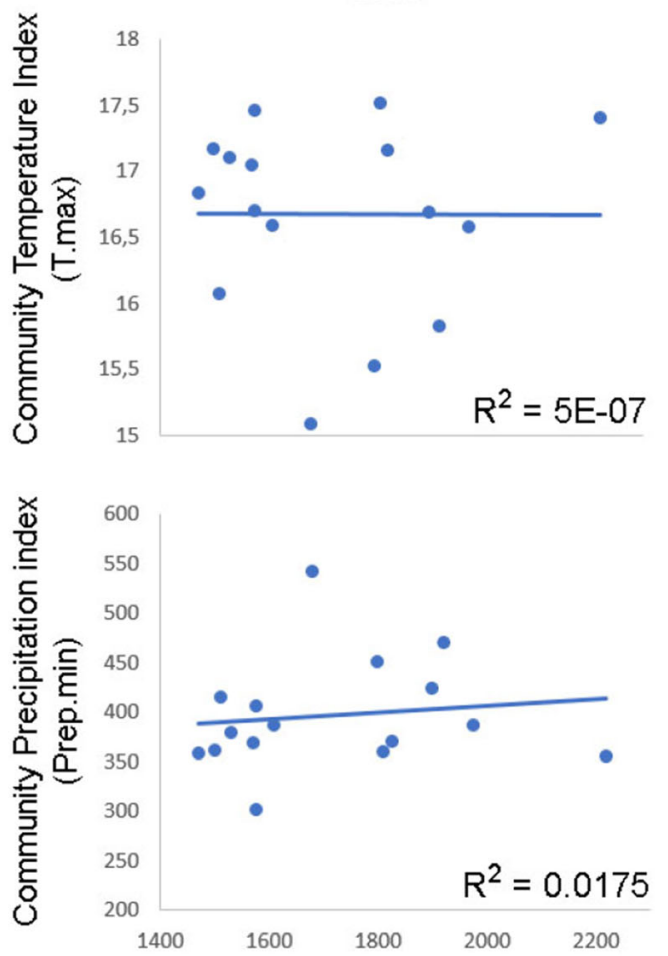

2004
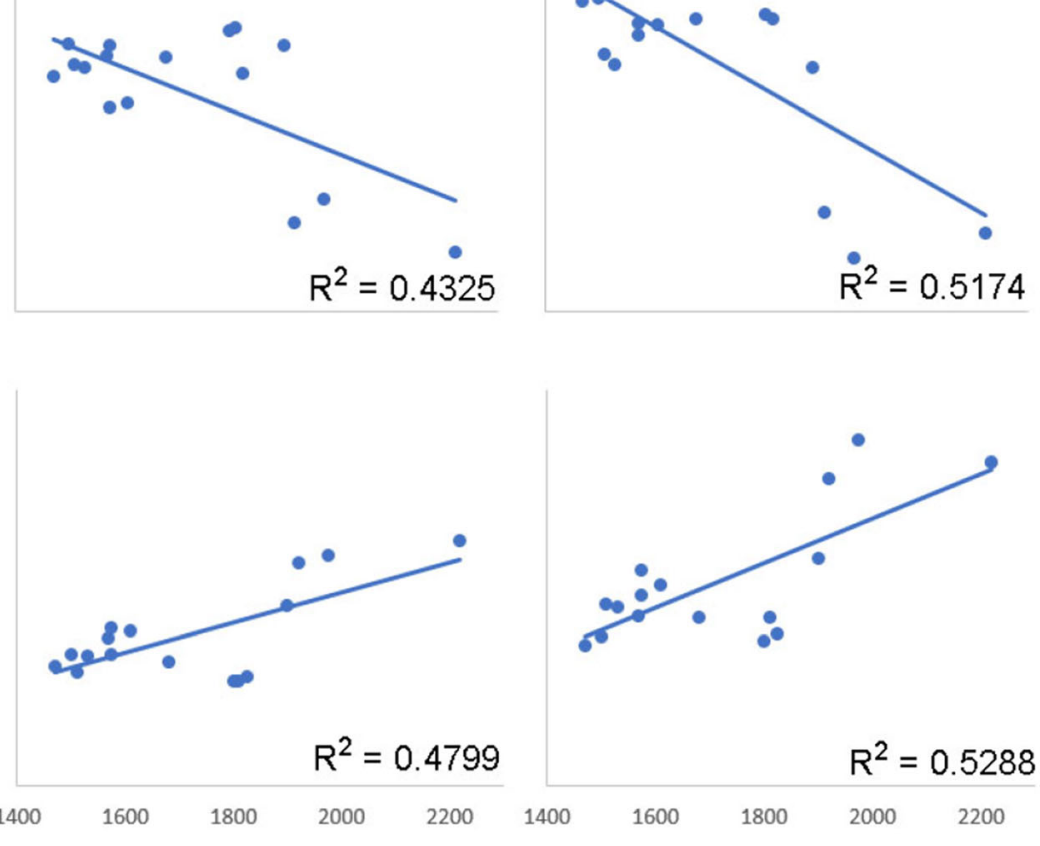

2012

altitude (m a.s.l.)

Fig. 4 Correlation between Community Temperature and Precipitation Indices and altitude of sites

composition. This is supported by the fact that both CTI and CPI were significantly different between 1975 and both of the more recent censuses, and not significantly different between the 2004 and 2012 censuses.

Across the European latitudinal gradient, it has been observed that limiting factors for butterfly species richness differ, with water availability as the prevailing factor in southern countries (Stefanescu et al. 2011; Herrando et al. 2019) and sunshine hours and temperature in northern ones (Turner et al. 1987). It has been observed that in Mediterranean countries species richness of butterfly communities varied according to observational scale and local characteristics. Wilson et al. (2007) estimated a regional decline of species richness of $90 \%$ in the Sierra de Guadarrama, Spain, because the uphill shift of the few low-elevation species presents in that region failed to compensate for the retreat of mountain species at higher altitude. In the Dadia National Park, Greece, the weak altitudinal gradient of this area $(20-650 \mathrm{~m})$ favored a decrease of high-elevation species and an increase of low-elevation species (Zografou et al. 2014). In Alpine sites, Cerrato et al. (2019) observed an increase in species richness over a short time period, similar to the one observed in northern Scandinavia over a long time period (Franzén and Öckinger 2012). Scarce evidence of a similar trend also arose from our study as species richness was higher in
2004 and 2012 than in 1975. However, 1975 and 2012 seemed to be more similar than 1975 and 2004, as during 2012, median and maximum values of diversity were the same of those registered in 1975, showing an increase only in minimum values. This could be due to our study design, which is affected by a phenological sampling bias. Although it is known that phenological changes occur as a response to climate warming, shifting the presence in the field of the winged stages (Roy and Sparks 2000; Bell et al. 2019), our sampling only covered 2 months of the butterfly activity season in order to cover the same time span as Balletto et al. (1977). A truncated monitoring season can produce data affected by differences in the phenology of species between years due to different climatic conditions. In fact, low and median values of species richness were significantly higher during 2004, when it was likely to have increased due to the presence of species usually flying earlier in the study area such as Boloria euphrosyne, Cupido minimus, and Melitaea cinxia. It is also interesting to note that in 2003, a major heat wave occurred, likely affecting the butterfly communities observed during 2004, e.g., favoring the observed outbreak of Lysandra coridon. In any case, although 2004 appears to be anomalous from quantitative (about half of the sample composed by L. coridon specimens) and qualitative (highest species richness) viewpoints, we found very similar results to those in 2012 
confirming the consistency of observed long-term trends in butterfly communities.

In this study, we found an evident change in community compositions across years, which led to a significant vertical stratification absent in 1975, observed firstly in 2004, and successively confirmed in 2012. This was the most interesting finding of this study. Results of abundance- and presence/ absence-based analyses are consistent, allowing us to exclude the possibility that observed patterns could be significantly affected by individual species outbreaks and or by the phenological shift of the flying period of few and not abundant species. In fact, presence/absence-based analyses do not take into account abundance of species, making these results unbiased by anomalous abundances of one or few species, whilst abundance based analyses are only slightly modified by the presence of few rare species in flight later than usual in a given period.

The vertical stratification of communities seems to be due to two concurrent changes in medium and low altitudinal bands: the increase of generalist and widespread species (Warren et al. 2001; Menéndez et al. 2007) and the reduction of cold-adapted ones (Zografou et al. 2014). In fact, most of the species having a positive trend of abundance and occupancy in the Pollino Massif are generalist ones, such as Colias crocea, Issoria lathonia, Aricia agestis, Pieris napi, and Papilio machaon. However, their increase is not homogeneous in all altitudinal bands. For example, the last three species have appeared in recent years only in low and medium altitude communities, with $A$. agestis and $P$. napi representing indicator species for the low altitudinal band. This likely happens because of the persistence of extreme environmental conditions above the treeline that confers resistance to the colonization of these species. On the other hand, coldadapted species suffer from the increase of temperature only at low altitude as demonstrated by the retreat of Erebia cassioides towards the top of the Pollino Massif where it increased its populations (Scalercio et al. 2014) and became the indicator species for the high altitudinal band.

Following the creation of the Pollino National Park in 1993, grazing pressure by cattle has been reduced. In other systems, this has been shown to lead to higher meadow vegetation and woody encroachment into meadow areas (Carmel and Kadmon 1999; Sternberg et al. 2000). In the Swiss Alps, the abandonment of hay-making and grazing on the mountaintops led to an upward shift in treeline, reclaiming historically forested lands, and dominating any effect of climate change (Gehrig-Fasel et al 2007). Higher meadow vegetation and woody encroachment can lead to local cooling and an increase in available moisture. For example, Körner (2003), in a European-wide study of alpine habitats, found that soil temperatures at $5-\mathrm{cm}$ depth was an average of $2^{\circ} \mathrm{C}$ warmer 200 $300 \mathrm{~m}$ above treeline than at treeline itself. If a similar process were occurring in the Pollino Massif, then the mountaintop alpine habitats would have undergone local cooling and become wetter. This would be consistent with the lowing of CTI and increase in CPI at the mountaintop sites in our study. However, there is a need of further studies to test this hypothesis. Unfortunately, historical data is lacking, but using, indirect evidence, such as the variation of the number of grazing cows across years, or comparisons of old and recent photographs of the same place may be possible in future studies. This possibility highlights the potential importance of expanding natural protected areas to help buffer wild mountaintop species against the detrimental effects of temperature increase in the Mediterranean Basin.

\section{Conclusions}

In the Mediterranean Basin, our study, coupled with others, demonstrate that butterfly communities have already been strongly modified by recent climate change and that these changes are especially prominent in mountainous areas. In the Pollino Massif, we found asymmetrical trends in butterfly communities along altitudinal gradients, with lower and mid-slope communities shifting towards hotter/drier associated species, and mountaintop communities shifting towards cooler/wetter associated species. Additionally, butterfly communities were more stable above treeline than below, in spite of general regional warming, possibly due to buffering effects of land-use changes, but this hypothesis could not be tested.

Author contribution SS conceived and designed the experiments. SS performed the experiments. LS, AI, and SS analyzed the data. SS, AI, and LS wrote the manuscript; all authors provided editorial advice.

Funding Open access funding provided by Università degli Studi di Napoli Federico II within the CRUI-CARE Agreement. Research supported by the Ministry of University and Education of Italy (PRIN D.M. 19 marzo 2010, n. 51, prot. 200947YRB9 Impact of global change on ecosystems, animal communities, and species of alpine and Mediterranean areas of Italy: models, scenarios, and evaluation from macro-scale to microscale, based on ecology and philogeography of vertebrates and invertebrates).

Open Access This article is licensed under a Creative Commons Attribution 4.0 International License, which permits use, sharing, adaptation, distribution and reproduction in any medium or format, as long as you give appropriate credit to the original author(s) and the source, provide a link to the Creative Commons licence, and indicate if changes were made. The images or other third party material in this article are included in the article's Creative Commons licence, unless indicated otherwise in a credit line to the material. If material is not included in the article's Creative Commons licence and your intended use is not permitted by statutory regulation or exceeds the permitted use, you will need to obtain permission directly from the copyright holder. To view a copy of this licence, visit http://creativecommons.org/licenses/by/4.0/. 


\section{References}

Altwegg R, Visser V, Bailey LD, Erni B (2017) Learning from single extreme events. Philos T R Soc B 372:20160141. https://doi.org/10. 1098/rstb.2016.0141

Andersen JC, Havill NP, Mannai Y, Ezzine O, Dhahri S et al (2019) Identification of winter moth (Operophtera brumata) refugia in North Africa and the Italian Peninsula during the last glacial maximum. Ecol Evol 9:13931-13941. https://doi.org/10.1002/ece3.5830

Balletto E, Toso G, Barberis G, Rossaro B (1977) Aspetti dell'ecologia dei Lepidotteri Ropaloceri nei consorzi erbacei alto appenninici. Animalia, Catania 4:277-343

Barnagaud J-Y , Devictor V, Jiguet F, Barbet-Massin M, Le Viol I et al (2012) Relating habitat and climatic niches in birds. PLoS One 7: e32819. https://doi.org/10.1371/journal.pone.0032819

Battisti A, Stastny M, Buffo E, Larsson S (2006) A rapid altitudinal range expansion in the pine processionary moth produced by the 2003 climatic anomaly. Glob Change Biol 12:662-671. https://doi.org/ 10.1111/j.1365-2486.2006.01124.x

Bell JR, Botham M, Henrys PA, Leech DI, Pearce-Higgins JW et al (2019) Spatial and habitat variation in aphid, butterfly, moth and bird phenologies over the last half century. Glob Change Biol 25: 1982-1994. https://doi.org/10.1111/gcb.14592

Blondel J, Aronson J, Bodiou JY, Boeuf G (2010) The Mediterranean region: biological diversity in space and time. Oxford University Press

Bowler D, Böhning-Gaese K (2017) Improving the community-temperature index as a climate change indicator. PloS one 12:e184275. https://doi.org/10.1371/journal.pone.0184275

Mingozzi T, Scalercio S, Passalacqua D, Rotondaro F, Pizzolotto R et al (2002) Stipa austroitalica garigues and mountain pastureland in the Pollino National Park (Calabria, Southern Italy). In: Redecker B, Finck P, Härdtle W, Riecken U, Schröder E (eds) Pasture landscapes and nature conservation. Springer, Berlin, pp 53-66

Brunetti M, Maugeri M, Fabio M, Nanni T (2006) Temperature and precipitation variability in Italy in the last two centuries from homogenised instrumental time series. Int J Climatol 26:345-381. https://doi.org/10.1002/joc.1251

Bucchignani E, Montesarchio M, Zollo AL, Mercogliano P (2016) Highresolution climate simulations with COSMO-CLM over Italy: performance evaluation and climate projections for the 21 st century. Int J Climatol 36:735-756. https://doi.org/10.1002/joc.4379

Carmel Y, Kadmon R (1999) Effects of grazing and topography on longterm vegetation changes in a Mediterranean ecosystem in Israel. Plant Ecol 145:243-254. https://doi.org/10.1023/A:1009872306093

Cerrato C, Rocchia E, Brunetti M, Bionda R, Bassano B et al (2019) Butterfly distribution along altitudinal gradients: temporal changes over a short time period. Nature Conserv 34:91-118. https://doi.org/ 10.3897/natureconservation. 34.30728

Colwell RK (2013) EstimateS: Statistical estimation of species richness and shared species from samples. Version 9. User's guide and application published at: http://purl.oclc.org/estimates.

De Cáceres M, Jansen F (2016) Indic species: relationship between species and groups of sites. R package version 1.7. 6. The Comprehensive R Archive Network

De Caceres M, Legendre P, Moretti M (2010) Improving indicator species analysis by combining groups of sites. Oikos 119:1674-1684. https://doi.org/10.1111/j.1600-0706.2010.18334.x

Despland E, Humire R, Martín SS (2012) Species richness and phenology of butterflies along an altitude gradient in the desert of Northern Chile. Arct Antarct Alp Res 44:423-431. https://doi.org/10.1657/ 1938-4246-44.4.423

Dewan S, Chettri IK, Sharma K, Acharya BK (2019) Kitam Bird Sanctuary, the only low elevation protected area of Sikkim: a conservation hotspot for butterflies in the Eastern Himalaya. J Asia-Pac Entomol 22:575-583. https://doi.org/10.1016/j.aspen. 2019.04.002

Diffenbaugh NS, Pal JS, Giorgi F, Gao X (2007) Heat stress intensification in the Mediterranean climate change hotspot. Geophys Res Lett 34:L11706. https://doi.org/10.1029/2007GL030000

Dufrêne M, Legendre P (1997) Species assemblages and indicator species: the need for a flexible asymmetrical approach. Ecol Monogr 67:345-366. https://doi.org/10.1890/0012-9615(1997)067[0345: SAAIST]2.0.CO;2

Franzén M, Öckinger E (2012) Climate-driven changes in pollinator assemblages during the last 60 years in an Arctic mountain region in Northern Scandinavia. J Insect Conserv 16:227-238. https://doi.org/ 10.1007/s10841-011-9410-y

Gao X, Giorgi F (2008) Increased aridity in the Mediterranean region under greenhouse gas forcing estimated from high resolution simulations with a regional climate model. Glob Planet Change 62:195209. https://doi.org/10.1016/j.gloplacha.2008.02.002

Giorgi F (2006) Climate change hot-spots. Geophys Res Lett 33:L08707. https://doi.org/10.1029/2006GL025734

Greco S, lenco A, Infusino M, Leonetti FL, Scalercio S (2018) New records of moths elucidate the importance of forests as biodiversity hot-spots in Central Mediterranean landscapes (Lepidoptera). Redia 101:147-154. https://doi.org/10.19263/REDIA-101.18.20

Grill A, Amori G, Aloise G, Lisi I, Tosi G et al (2009) Molecular phylogeography of European Sciurus vulgaris: refuge within refugia? Mol Ecol 18:2687-2699. https://doi.org/10.1111/j.1365294X.2009.04215.x

Herrando S, Titeux N, Brotons L, Anton M, Ubach A et al (2019) Contrasting impacts of precipitation on Mediterranean birds and butterflies. Sci Rep 9. https://doi.org/10.1038/s41598-019-42171-4

Infusino M, Greco S, Turco R, Bernardini V, Scalercio S (2016) Managed mountain forests as diversity reservoirs in Mediterranean landscapes: new data on endemic species and faunistic novelties of moths. Bullet Insectology 69:249-258

Konnert M, Bergmann F (1995) The geographical distribution of genetic variation of silver fir (Abies alba, Pinaceae) in relation to its migration history. Plant Syst Evol 196:19-30. https://doi.org/10.1007/ BF00985333

Körner C (2003) Alpine plant life: Functional plant ecology of high mountain ecosystems. Springer-Verlag, Berlin

Médail F, Diadema K (2009) Glacial refugia influence plant diversity patterns in the Mediterranean Basin. J Biogeogr 36:1333-1345. https://doi.org/10.1111/j.1365-2699.2008.02051.x

Médail F, Quézel P (1999) Biodiversity hotspots in the Mediterranean Basin: setting global conservation priorities. Conserv Biol 13:1510 1513. https://doi.org/10.1046/j.1523-1739.1999.98467.x

Menéndez R, González-Megías A, Collingham Y, Fox R, Roy DB et al (2007) Direct and indirect effects of climate and habitat factors on butterfly diversity. Ecology 88:605-611. https://doi.org/10.1890/ 06-0539

Molina-Martínez A, León-Cortés JL, Regan HM (2013) Climatic and geometric constraints as driving factors of butterfly species richness along a Neotropical elevational gradient. J Insect Conserv 17:11691180. https://doi.org/10.1007/s10841-013-9598-0

Myers N, Mittermeier RA, Mittermeier CG, Da Fonseca GA, Kent J (2000) Biodiversity hotspots for conservation priorities. Nature 403:853. https://doi.org/10.1038/35002501

Oksanen J et al (2014) Vegan: Community Ecology Package. R Package 280

Parmesan C, Ryrholm N, Stefanescu C, Hill JK, Thomas CD et al (1999) Poleward shifts in geographical ranges of butterfly species associated with regional warming. Nature 399:579. https://doi.org/10.1038/ 21181

Pizzolotto R, Sapia M, Rotondaro F, Scalercio S, Brandmayr P et al (2010) A georeferenced biodiversity databank for evaluating the 
impact of climate change in southern Italy mountains. In: Körner C, Spehn EM (eds) Data mining for global trends in mountain biodiversity. CRC Press, Taylor \& Francis, Boca Raton, pp 137-147

Pollard E (1977) A method for assessing changes in the abundance of butterflies. Biol Conserv 12:115-134. https://doi.org/10.1016/00063207(77)90065-9

Pounds JA, Fogden MP, Campbell JH (1999) Biological response to climate change on a tropical mountain. Nature 398:611-615. https://doi.org/10.1038/19297

R Core Team (2019) R: a language and environment for statistical computing computer program, version 3.6. 1. R Core Team, Vienna

Roy DB, Sparks TH (2000) Phenology of British butterflies and climate change. Glob Change Biol 6:407-416. https://doi.org/10.1046/j. 1365-2486.2000.00322.x

Scalercio S (2009) On top of a Mediterranean Massif: Climate change and conservation of orophilous moths at the southern boundary of their range (Lepidoptera: Macroheterocera). Eur J Entomol 106:231239. https://doi.org/10.14411/eje.2009.031

Scalercio S, Bonacci T, Mazzei A, Pizzolotto R, Brandmayr P (2014) Better up, worse down: bidirectional consequences of three decades of climate change on a relict population of Erebia cassioides. J Insect Conserv 18:643-650. https://doi.org/10.1007/s10841-0149669-x

Schweiger O, Harpke A, Wiemers M, Settele J (2014) CLIMBER: Climatic niche characteristics of the butterflies in Europe. ZooKeys 367:65. https://doi.org/10.3897/zookeys.367.6185

Schweiger O, Settele J, Kudrna O, Klotz S, Kühn I (2008) Climate change can cause spatial mismatch of trophically interacting species. Ecology 89:3472-3479. https://doi.org/10.1890/07-1748.1

Shoo LP, Williams SE, Hero JM (2006) Detecting climate change induced range shifts: where and how should we be looking? Austral Ecol 31(1):22-29. https://doi.org/10.1111/j.1442-9993.2006.01539. $\mathrm{x}$

Siegmund P et al (2019) The global climate in 2015-2019. World Meteorological Organization, Geneva

Sparks TH, Roy DB, Dennis RLH (2005) The influence of temperature on migration of Lepidoptera into Britain. Glob Change Biol 11:507514. https://doi.org/10.1111/j.1365-2486.2005.00910.x

Stefanescu C, Carnicer J, Peñuelas J (2011) Determinants of species richness in generalist and specialist Mediterranean butterflies: the negative synergistic forces of climate and habitat change. Ecography 34:353-363. https://doi.org/10.1111/j.1600-0587.2010. 06264.x
Sternberg M, Gutman M, Perevolotsky A, Ungar ED, Kigel J (2000) Vegetation response to grazing management in a Mediterranean herbaceous community: a functional group approach. J Appl Ecol 37:224-237. https://doi.org/10.1046/j.1365-2664.2000.00491.x

Tamanini L (1961) Ricerche zoologiche nel Massiccio del Pollino (Lucania-Calabria). XXX. Emitteri Eterotteri (Hemiptera Heteroptera). Annuar Ist Mus Zool Univ Napoli 13:1-128

Thomas CD (2010) Climate, climate change and range boundaries. Divers Distrib 16:488-495. https://doi.org/10.1111/j.1472-4642. 2010.00642.x

Turner JR, Gatehouse CM, Corey CA (1987) Does solar energy control organic diversity? Butterflies, moths and the British climate. Oikos 1987:195-205. https://doi.org/10.2307/3565855

van Swaay CA, Nowicki P, Settele J, van Strien AJ (2008) Butterfly monitoring in Europe: methods, applications and perspectives. Biodivers Conserv 17:3455-3469. https://doi.org/10.1007/s10531008-9491-4

Visser ME, Holleman LJ (2001) Warmer springs disrupt the synchrony of oak and winter moth phenology. Proceedings of the Royal Society of London. P Roy Soc B-Biol Sci 268:289-294. https://doi.org/10. 1098/rspb.2000.1363

Warren MS et al (2001) Rapid responses of British butterflies to opposing forces of climate and habitat change. Nature 414:65. https://doi.org/ $10.1038 / 35102054$

Wiemers M, Balletto E, Dincă V, Fric ZF, Lamas G et al (2018) An updated checklist of the European butterflies (Lepidoptera, Papilionoidea). ZooKeys 811:9. https://doi.org/10.3897/zookeys. 811.28712

Wilson RJ, Gutierrez D, Gutierrez J, Martínez D, Agudo R et al (2005) Changes to the elevational limits and extent of species ranges associated with climate change. Ecol Lett 8:1138-1146. https://doi.org/ 10.1111/j.1461-0248.2005.00824.x

Wilson RJ, Gutierrez D, Gutierrez J, Monserrat VJ (2007) An elevational shift in butterfly species richness and composition accompanying recent climate change. Glob Change Biol 13:1873-1887. https:// doi.org/10.1111/j.1365-2486.2007.01418.x

Zografou K, Kati V, Grill A, Wilson RJ, Tzirkalli E et al (2014) Signals of climate change in butterfly communities in a Mediterranean protected area. PLoS One 9:e87245. https://doi.org/10.1371/ journal.pone. 0087245

Publisher's note Springer Nature remains neutral with regard to jurisdictional claims in published maps and institutional affiliations. 